\title{
Control of initial steps of ciliogenesis by protein kinases
}

\author{
R Carvalho, W Wang, G Pereira* \\ From Cilia 2014 - Second International Conference \\ Paris, France. 18-21 November 2014
}

Cilia are microtubule-based organelles present on the surface of most vertebrate cells. The formation of the primary cilia requires the mother centriole, which is the older of the two centrioles, to convert into the ciliary basal body. Although recent research has begun to shed light onto the molecular composition of the cilium, the regulation of ciliogenesis is just beginning to be understood. To get insight on the molecular mechanisms that regulate basal body formation, we performed a high-throughput RNA interference screen to identify protein kinases required for ciliogenesis. Of the novel kinases we identified, we are characterizing the function of the microtubule associated/ affinity regulating kinase 4 (MARK4), and tau-tubulin kinase 2 (TTBK2). We show that MARK4 and TTBK2 are both required to initiate axoneme extension and to promote the removal of the inhibitory protein complex composed of CP110/Cep97. Together, our data indicate that cilia formation is a highly regulated process, which requires the concerted action of protein kinases that regulate the transition from the mother centriole into the basal body.

Published: 13 July 2015

doi:10.1186/2046-2530-4-S1-O4

Cite this article as: Carvalho et al:: Control of initial steps of ciliogenesis

by protein kinases. Cilia 2015 4(Suppl 1):04.

German Cancer Research Centre (DKFZ), DKFZ-ZMBH Alliance and University of Heidelberg, Heidelberg, Germany

(c) 2015 Carvalho et al. This is an Open Access article distributed under the terms of the Creative Commons Attribution License (http:// creativecommons.org/licenses/by/4.0), which permits unrestricted use, distribution, and reproduction in any medium, provided the original work is properly cited. The Creative Commons Public Domain Dedication waiver (http://creativecommons.org/publicdomain/ zero/1.0/) applies to the data made available in this article, unless otherwise stated.

Submit your next manuscript to BioMed Central and take full advantage of:

- Convenient online submission

- Thorough peer review

- No space constraints or color figure charges

- Immediate publication on acceptance

- Inclusion in PubMed, CAS, Scopus and Google Scholar

- Research which is freely available for redistribution Biomed Central

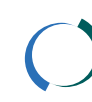

Berised Central 